\title{
Nonpolar Europe? Examining the causes and drivers behind the decline of ordering agents in Europe
}

\author{
Hiski Haukkala ${ }^{1}$ \\ Published online: 15 July 2020 \\ (c) Springer Nature Limited 2020
}

\begin{abstract}
Is Europe headed towards nonpolarity? What would that entail for the future stability and security of the continent? Taking its cue from IR debates about the effects of polarity on international order, the article develops conceptual tools and an analytical narrative concerning Europe during the post-Cold War era. It refines the concept of a Great Power by suggesting the notion of 'ordering agents' and ponders whether Europe is in danger of drifting towards a period of nonpolarity with no power being able to shoulder the responsibility of ordering and providing good stewardship over Europe.
\end{abstract}

Keywords Polarity $\cdot$ Order $\cdot$ Ordering agents $\cdot$ Nonpolarity $\cdot$ Europe $\cdot$ Russia

\section{Introduction}

For the past five centuries, Europe has been the veritable centre of the world. At first the Europeans developed the modern conceptions of statehood and international politics and then actively projected these innovations through the application of a 'standard of civilisation' well beyond the continent's boundaries (Bull and Watson 1984). In the process, an increasingly global international system was formed, and it has been one where the Europeans have continued to enjoy a pride of place.

The Europeans have also been one of the main sources as well as beneficiaries of western international order. Since the end of the Cold War, it has rested on US primacy, but it is a wider western phenomenon that has resulted in a liberal and rulebased world order (Ikenberry 2018). In Europe, it has been manifest in a concentric hegemonic order where the US global primacy and regionally preponderant security role through NATO have been complemented by the European Union (EU) that has assumed the position of a regional normative hegemon in its own right (Haukkala

Hiski Haukkala

hiski.haukkala@tuni.fi

1 Faculty of Management and Business, Tampere University, Pinni A4079, FI-33014 Tampere, Finland 
2008) with a view of ordering the continent along essentially unipolar lines by envisaging a Europe of concentric circles revolving around 'Brussels' (Aalto 2006; Diez and Whitman 2002). In Europe, the USA and the EU have formed a 'matryoshka hegemony' (Deyermond 2009) of sorts that has sought to, and largely succeeded in ordering the continent in a largely unified, or at least complementary manner.

For many, these developments have been welcome and benign. Unarguably Europe has never been as stable and secure as it has been for the past three decades. Yet there are growing signs that this era is coming to an end. On the global level, the USA has entered a period of retrenchment with tensions increasing with the rapidly rising China (Allison 2017). Under President Donald Trump, it has also largely abdicated its global leadership role and the liberal rule-based international order is under an immense and growing strain (Sørensen 2019). China together with Russia and other smaller regional powers is challenging the current international order on the global level while staking their claims for regional spheres of influence. This is visible also in Europe where Russia has for some time been making the case for a more equitable bipolar setting. This process of contestation culminated in the Ukraine conflict in 2014 that has resulted in a low-simmering conflict between the West and Russia.

Taking its cue from International Relations (IR) debates about the effects of polarity (the number of Great Powers) on the evolution of international order (for a chronological lineage, see Waltz 1979; Kegley and Raymond 1994; Mearsheimer 2001; Brooks and Wohlforth 2008; Monteiro 2014), this article poses the question whether Europe is experiencing not only a period of 'normal' geopolitical contestation, but could it in fact be in a transition towards a state of affairs where it will become void of Great Powers capable of effectively ordering the continent, let alone the wider world. In a word, is Europe headed towards a period of nonpolarity? And if so, what would it entail for the future of cooperation, stability and even security on the continent?

The article makes three main contributions. Firstly, it links European studies with IR debates concerning polarity and the ongoing change in the structure of international politics. It situates itself in the so-called third wave of hegemony studies (Ikenberry and Nexon 2019), but concentrates on examining the unravelling of western hegemony in Europe. Secondly, it seeks to conceptually expand our understanding of Great Powerhood by introducing the notion of 'ordering agents'. The article seeks to add nuance to the extant literature that has largely simply assumed that Great Powers are always also capable of generating order. Instead, the article draws attention to a whole gamut of prerequisites for successful ordering role in contemporary international politics. Moreover, it is argued that these requirements are particularly salient in Europe that is undoubtedly the most highly institutionalised region in the world (Diez and Whitman 2002). Thirdly, the article presents an analytical narrative concerning the developments in Europe during the post-Cold War era. It does so in two stages: firstly recounting the story of western attempts at hegemonic ordering of Europe and Russia's growing contestation of it, and then moving on to analysing the main causes and drivers behind potential nonpolarity in Europe.

The argument will be developed in four stages. Firstly, the concepts of (non) polarity and Great Powerhood are introduced and refined with a view of introducing 
the concept of 'ordering agents'. Secondly, the roles that the USA, the European Union and Russia have played in ordering Europe during the post-Cold War era are analysed. Thirdly, the causes, drivers and consequences of nonpolarity in Europe are discussed. Finally, the article concludes by pondering the question whether Europe indeed is headed towards a period of nonpolarity and what that could entail for the future of the continent. It ends with a policy relevant point by warning about the possible unintended consequences of current contestation and institutional atrophy in Europe. The article suggests that the current trajectory is not in the best interest of any party and engages in some normative argumentation by contending that in the twenty-first century a Great Power worthy of the name should be held to a higher standard in terms of providing building blocks for stability and order on both the regional and global levels than is currently the case.

\section{Power, order and (non)polarity}

Often order is the norm in everyday life. This is the case in our domestic societies where the monopoly on the legitimate use of violence enjoyed by the states ensures a hierarchical and, at least most of the time, also orderly conduct of our national politics. The anarchical international system does not lend to a clear-cut hierarchy along the domestic lines, but it is not entirely without order, either, that for the purposes of this article is defined as (sub-)systemwide structures and practices-institutions, norms, values and principles - that govern and regulate the conduct of international politics.

In international politics, order stems mainly from two sources (see Young 1989: 88-89 from which the following is taken). It may emerge spontaneously generated by the 'hidden hand' of international anarchy. Oran Young has called these self-generated orders, the classic example of which is the principle of balance of power that has at times been rather successful in moderating interstate conflict (Little 2014). Yet for the purposes of this article, and indeed the increasingly interdependent and global international system in which we find ourselves, this is too rudimentary and in effect shallow conception of order. Therefore, the other, and arguably more important, avenue for generating order is that of premeditated design. In Young's terminology, these imposed or negotiated orders require intentional agency on the part of key actor(s) that take the lead, or act in concert, in generating, upholding and, at times, modifying and even undoing orders.

There is nothing automatic in this latter type of order generation, as it takes effort and the use of power to achieve. In the final analysis, it requires not only great power but Great Power(s) to generate and uphold an international order. But being a Great Power is not in itself enough, as one must also be both able to conduct the ordering role and willing to carry the associated burden. Therefore, it is suggested in this article that order-generating Great Powers are a particular subset of the category that should be called ordering agents that are defined here as a Great Power that has the capacity, ability and willingness to establish, uphold and project (sub-)systemwide ordering structures and practices-institutions, norms, values and principles-and, 
as a consequence, to have intended/desired ordering effects. The essential building blocks of a successful ordering agent are summarised in Table 1.

Let us begin with capacity. This refers to power that is perhaps the most essential concept in the study of international politics (Baldwin 2002: 177). It is also one of the most contested ones. This is not the occasion to try to settle these debates; suffice it to say, that a multifaceted conception of power is called for. The key question here pertains to the quantity and quality of power as well as its varying effects when employed in ordering the international. According to Waltz (1993: 50), Great Powers require a whole spectrum of attributes: size of population and territory, resource endowment, economic capability, military strength, political stability and competence. Traditionally the master variable has been military power, which in an anarchic setting is the ultimate arbiter of conflicts between states. Yet it is possible to overstate its relevance, especially in our global and interdependent world (Nye 2011). Other forms of power, ranging from economic to 'soft' and normative, play an increasingly important role (Baldwin 1989; Nye 2004; Manners 2002). It is also noteworthy that military power does not ensure reliable control over outcomes across the board of relevant issues in contemporary international politics: States can employ strategies that offset military power differentials and they can have meaningful geopolitical effects despite not being fully credible peer competitors. Indeed, an actor may have the power to affect the behaviour of others through disruptive forms of power-power to avoid nonpreferred outcomes or simply acting as a spoilerwithout necessarily being fully able to coerce others into adopting a stance preferred by the actor. Also, if military power is the hammer, not every issue of consequence in contemporary international politics is a nail. On the contrary, there are plenty and perhaps even increasingly issues in the world today that cannot be solved, nor necessarily even contained with the use of military power. The question of climate change as well as other systemic risks, such as pandemics, is a case in point (Goldin and Mariathasan 2016). The same applies to the disruptive forms of power, as they do not generate collective capacity for problem-solving and governance.

Therefore, identifying the existence of Great Power capacity in the abstract is only the first step in the analysis. Without the ability to channel, or translate, that capacity into actual influence they remain only resources, void of actual ordering effects (see also Sørensen 2019: 59). Analysing power differentials is imperative, yet it does not tell us anything about the quality of interaction and the nature of consequent contestation and ordering between the Great Powers. The exercise of power is always an empirical issue: it is an outcome of interaction and it cannot be deducted from power differentials alone, regardless of how significant they may be (ArreguinToft 2001).

To gain a more nuanced view of the processes at play, one can turn to the English School and the seminal work of Hedley Bull. He was one of the first theorists who argued that an order is not merely a pattern that grows out of mechanical interaction between like units, but it is an intentional and in the final analysis also inherently social process where the key actors take the lead in generating and upholding a particular conception of order that rests on a set of shared values, norms and institutions (Bull 1995). For Bull, it was indeed the existence of shared institutions, such as balance of power and international law, that formed the basis of what he called 


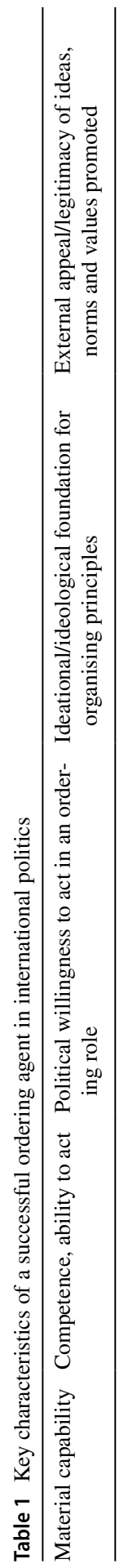


'international society'. But for him the common institutions represented something shared and universal. Halliday (1994: 101) has pointed out how Bull's international society is 'communitarian', implying a group with shared values. He also did not address the question of change, but adopted a rather conservative stance, advocating relative perpetuity in the constitution of the international society (see Friedner Parrat 2017). In Bull's reading, norms, values and institutions were static and, by and large, seen at the same time as both prerequisites for and in their operation beneficial to the existence of an international society.

The point is not that Bull was entirely off the mark, however. International order always serves the interests of the wider international society, but does so unevenly. It is important to bear in mind Anna Leander's (2006: 371) insightful words that an order is never neutral: it always works to the advantage of some and to the (at least potential) disadvantage of others, inviting us to ask whose international order we are talking about (see also Williams 2006: 24). In this interpretation, an international order does not only serve certain useful functions for the society at large, but it also reflects the interests and ideas of certain key players of that society. Therefore, an international order is never neutral, nor is it necessarily an entirely voluntary exercise on the part of all its members: a certain amount of co-optation and coercion, at times perhaps even domination is to be expected. The stance taken here is that when it comes to the question of order in international politics, norms, practices and institutions should be viewed as sites of contestation and struggle: in the final analysis, it is their content that reflects both the power and the ideas of those who are able to affect change in them (Wiener 2014; see also Ikenberry and Nexon 2019; Wivel and Paul 2019). In this reading, a choice between power and ideas is a false dichotomy: It is not either ideas or power but both that will be required to make sense of any given international order (Sørensen 2008). Although at times a single actor-or a group of actors acting in concert-may be powerful enough to dictate the rules of the game on others, brute strength alone is usually not enough to recalibrate international order.

All these point towards the role of intentional agency. Order does not change by itself, but it is changed by wilful actors who are able to affect that change. Nor does an order sustain itself on its own, but it requires agents that seek to uphold it. This refers to the third variable in our definition, namely the willingness to act as an ordering agent and to carry the associated burden. Here, Ikenberry's (2001) treatment of international order as a process where the leading state(s) has sought to lock other states into a certain set of institutionalised practices is a useful starting point. In addition, order has always entailed a viable domestic model and the projection of its essential elements beyond borders to generate that very order. This is the case in two different respects. Firstly, a viable domestic model is a prerequisite for effective agency: you can only function as an ordering agent internationally if you first function to a satisfactory degree internally. Secondly, the reconstitution of an international order must also rely on legitimacy: of the actors involved and the normative foundation promoted (Cf. Hoffmann 1990: 19-20; Philpott 2001: 355-356). In the words of Georg Sørensen (2019: 57), 'a stable and legitimate order is founded on a fit among a power base..., a common collective image of order expressed in values and norms, and an appropriate set of institutions'. 
The last conceptual issue that needs to be discussed in this context deals with the relationship between Great Power politics and polarity, i.e. the number of Great Powers in any given international system (Waltz 1979: 72). Power is obviously the key consideration in deciphering the number of Great Power poles: To count as one, their relative capabilities must be roughly commensurate across all domains with the most powerful state in the world. According to Kegley and Raymond (1994: 75) in a bi-/multipolar system, Great Powers must be near, but not necessarily absolute equals.

The number of poles has varied historically, but in general multipolarity-the existence of more than two poles in the system - has been the norm (see Kegley and Raymond 1994). Indeed, the post-World War II eras stand out in a sense that they witnessed, first, a period of intense rivalry between two superpowers locked into a bipolar setting during the Cold War, followed by the period of unipolarity with the USA enjoying unrivalled primacy and hegemony during the post-Cold War era (Monteiro 2014; Brooks and Wohlforth 2008). See Table 2 for a summary of Great Powers in Europe during the modern era.

Table 2 shows how although polarity has varied historically, the issue of nonpolarity has not arisen during the modern era. At first sight, the whole notion of nonpolarity might seem odd: Surely we are not anticipating the wholesale collapse of the state-centric international system and the disappearance of Great Powers with it. ${ }^{1}$ To better understand how nonpolarity in the European context might be possible and perhaps even likely, we must examine the question of polarity in light of our definition of ordering agents.

In its established usage, the relationship between Great Powers and polarity is almost tautological—Great Powers are poles and vice versa. But for the present purposes this is not analytically very useful. Instead, the article contends that polarity in its traditional reading is a bird's-eye view of international politics based on resources and potential, whereas a more useful analytical lens would take into account the other aspects of agency, namely the ability and willingness to act as an ordering agent in the sense defined above. This entails that to count as a pole, the agent in question must be in possession of a host of attributes: a material power base, ideational foundation and perceived external legitimacy to begin with, but also a political variable concerning the essential competence to act as an ordering agent in international politics and willingness to carry the associated burdens.

In light of this discussion, we may define nonpolarity as the lack of Great Powers that are capable, able and willing to act as ordering agents in a given international system or its sub-system. The term nonpolarity was introduced by Richard N. Haass who in his article written for Foreign Affairs over a decade ago defined it loosely as an 'international system... characterised by [too] numerous centres with meaningful

\footnotetext{
1 This is not, in fact, suggested by this article, although it might not be as far-fetched as it may seem. Some scenarios concerning a possibly catastrophic runaway climate change suggest the possibility of the collapse of civilisation, the most powerful actors included. This possibility is also one of the reasons why the period of potential nonpolarity in Europe is so worrisome: it detracts from our ability to deal effectively with the issue, among others.
} 


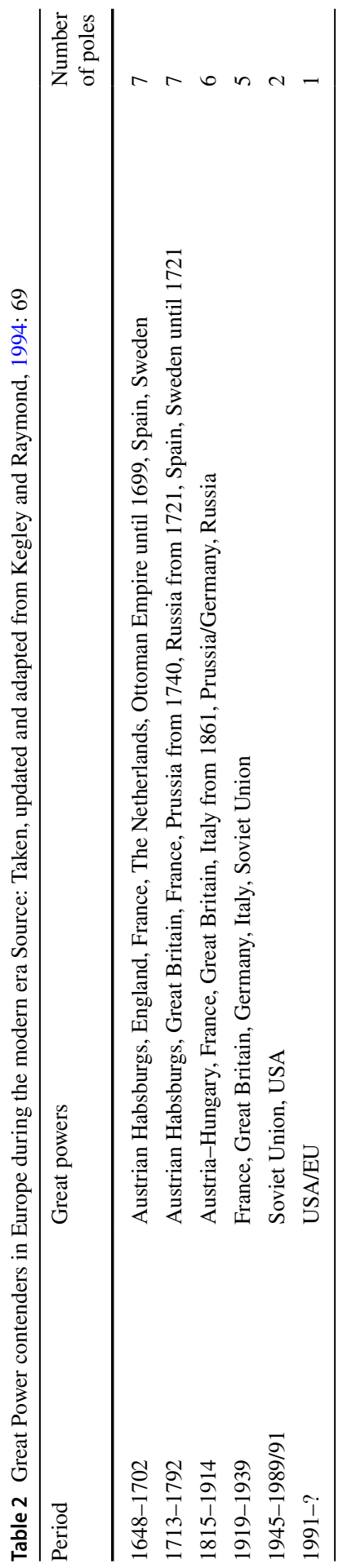

称 
power' (Haass 2008; see also Bremmer 2012 who spoke about a 'G-0 world'). Yet the use of the term in this article differs from Haass's conception in two respects. First, it is regional in scope, drawing attention to Europe instead of overall global politics. Second, it does not assume that power has drifted away to or been diffused by a host of nonstate actors to a degree that would account for nonpolarity. On the contrary, the article argues that the potential period of nonpolarity stems from changes that are taking place within the key actors at play: their indigenous capacity and willingness to act as ordering agents are atrophying. In addition, nonpolarity is also an outcome generated by the current interaction and growing contestation between the main contenders for an ordering role. In short, nonpolarity is a situation where Great Powers are either incapable or unwilling, either alone or in concert, to apply power to successfully create or uphold an international order in Europe.

\section{The trajectory of western unipolar hegemony in Europe}

The dissolution of the Soviet Union and the end of the Cold War division opened (geo)political space in Europe. The rigid bipolar confrontation gave way to a much more fluid setting where fresh opportunities and challenges rapidly mushroomed. This called for new policies on the part of both the USA and the emerging EU. For the USA, the four main objectives were: (1) managing the transition to a new postCold War order in a peaceful and orderly fashion; (2) facilitating the emergence of Russia as a successor state of the Soviet Union as a responsible and constructive player, including the development of cooperative threat reduction with Russia to deal with the toxic assets left behind by the Soviet Union; (3) ensuring the primacy of NATO — and by extension also the USA — in European security, and downplaying the EU's potential to emerge as a fully independent security actor; while (4) using that very EU as a proxy to organise political and economic integration and consequent transition in the emerging wider Europe. (For a discussion concerning the key tenets of US policy, see Goldgeier and Mcfaul 2003; Talbott 2002; Stent 2014.)

The USA took the lead in ordering the post-Cold War setting along liberal lines, first in Europe and then increasingly also globally (Mearsheimer 2019). For quarter of a century, the USA was able to secure an unrivalled position at the top of international hierarchy. It was also successful in stabilising the conflicts in Europe during the 1990s while locking most of the continent into its preferred security structure through the expansion of NATO (Mastanduno 1997). Even if Russia made some dissatisfied noises at the time, there was an expectation that it, too, could be successfully placated by offering Moscow some privileged forms of partnership with the West and the USA in particular (Asmus 2002).

The EU's rise to prominence dovetailed these developments. In the early 1990s, it started to express ambitions and develop capacities for indigenous views about international affairs and to develop them into policies and actions on the world stage. The adoption of the Common Foreign and Security Policy (CFSP) in the Maastricht Treaty of 1991 was of particular significance, as it created fresh instruments for external action and institutionalised a cooperative culture that over time have resulted in impressive, although perhaps needlessly cumbersome, finesse and 
complexity in today's EU (see Keukeleire and Delreux 2014). In the process, the EU was effectively thrust into assuming a leading role in responding to the economic effects of the dissolving Soviet empire.

The objectives of the nascent 'European foreign policy' and those of the USA were largely compatible and even complementary to each other. One way to characterise the role the two played in ordering Europe is to think of 'matryoshka hegemony' where the US global primacy and regionally preponderant security role through NATO set the broad liberal framework within which the EU took the lead in ordering the European continent through the expansion and outward projection of its policies, norms and values (Haukkala 2008). Consequently, the USA and the EU, working in tandem, met practically all the requirements for a successful ordering agent in Europe: they enjoyed unrivalled material preponderance while portraying both competence and political willingness to act as ordering agents. They also promoted a coherent set of idea(l)s and did so during a period when their leading role enjoyed a great deal of external legitimacy, reflected in the long queues of accession candidates in front of both NATO's and the EU's doors.

Having established this, one should exercise some caution in assigning too much strategic intentionality on the part of the West. Both NATO's and the EU's eventual Sprung nach Osten were more reactions and responses to events and demands beyond the West's control or initial appetite rather than preconceived programmes to order or subjugate the whole continent to their will (see Asmus 2002; Smith 1999; Hill 2018). The hegemonic underpinnings of their ordering role were arrived at in a piecemeal, almost haphazard manner. This gives the western unipolar hegemony over Europe a paradoxical quality. To a degree, this also explains why it fizzled out so quickly in the face of growing Russian resistance.

For quite some time, Russia remained an outlier to the western attempts at ordering Europe. It was not fully in nor fully out, while it was trying to figure out its own national interests and international identity. In the process, Russia has developed an increasingly strained relationship with both the USA and the EU and adopted a highly belligerent approach towards the concentric order they have been propagating. For the Russians, the crux of the issue was that it lacked a voice and a role that would have been commensurate with its own self-image as a Great Power. One way to interpret the events during the last quarter century in Europe is to view it as a process of increasing frictions and tensions between the Western NATO/EU-centric attempts at ordering the continent and Russia's growing frustration and even hostility towards its inability to secure a place for itself that would have allowed it a voice and a veto (Marten 2017). In the words of Hill (2018), in the eyes of Moscow the European architecture has left 'no place for Russia'.

Related to this is the wider Russian complaint concerning the role the USA has played globally. The US post-Cold War primacy in general and the way Washington responded to the 9/11 terrorist strikes in 2001 accentuated the Russian impression of a rampant USA bent on dominating the world unilaterally. In Vladimir Putin's resentful words, uttered already in 2007, the USA had 'overstepped its national borders in every way' (Putin 2007). Positioning itself as a counterforce to a reckless and domineering Washington became the leitmotif of Putin's rhetoric and Russian foreign policy well before the dramatic events in Ukraine. 
Although not felt as keenly at the time, the EU enlargement also created its own frictions between Russia and the West. In particular, the question of a 'common/ shared neighbourhood' created in the aftermath of the 'Big Bang' eastern enlargement of 2004 proved to be a source of tensions. Ukraine's 2004 Orange Revolution-which took both the West and Russia equally by surprise-changed Moscow's tack concerning the EU's role in the region. Moscow's previous benign neglect subsided, as it began to view the EU's growing role and the western orientation of the CIS countries with increasing suspicion (Gretskiy et al. 2014). Although it was not appreciated at the time, the Orange Revolution was the starting gun for the preparation of operations and practices witnessed first in Georgia in 2008 and then in Crimea and Eastern Ukraine since 2014 (Franke 2015).

Over time Russia's grudging acquiescence to western liberal hegemony morphed into outright opposition. Yet the current conflict between Russia and the West was far from inevitable. On the contrary, in early 2000s both parties were still looking for ways to make the relationship work. (For accounts that testify to this effect, see Forsberg and Haukkala 2016; Stent 2014.) These repeated attempts at 'resets' and other fresh beginnings were marred by the underlying and largely irreconcilable tension where the western unipolarity, however, well intended, ran counter to the growing Russian calls for a more equitable and essentially bipolar setting in Europe.

By the end of 2000s, Russia started to take much more assertive steps to promote its preferred vision of order beyond its borders. In the first instance, this took the form of the Eurasian Economic Community (EurAsEC) that soon became the Eurasian Economic Union (EAEU) through which Russia started to invest in a more institutionalised bipolar setting in Europe, with Moscow as the leading power in the other half of the continent with the expectation of attracting the majority, if not all, of the post-Soviet states under Russia's leadership (see Dragneva and Wolczuk 2013). Although the EAEU did gain some initial momentum, as exemplified by the expansion of its members from the original three to current five, the fact that Russia felt compelled to resort to open blackmail and coercion to attract new members to the EAEU speaks volumes about the power of attraction of the new regional bloc.

The conflict in Ukraine was the culmination of these unhappy trends (Haukkala 2016). With its actions, Russia made abundantly clear that it views Eastern Europe as its primary sphere of interests (Trenin 2009) that both the EU and NATO must respect and that it is willing to use all the means at its disposal to enforce this policy. Russia also signalled its readiness to pay a high price in terms of economic hardship and international, although mainly western, opprobrium for doing so (Menon and Rumer 2015; Wilson 2014). The reasons for this are myriad, but the main point worth stressing is that the near-existential nature of Russian interests in and over Eastern Europe creates an asymmetry that is unfavourable to the West: no matter how hard it pushes its version of order on the East, Moscow is always willing to push back a little harder - and accept the eventual price for doing so.

In other words, Russia has been stable, able and ruthless enough to act as a spoiler in Europe, but, apart from the EAEU that contains severe internal tensions and contradictions, as exemplified by the catastrophic outcome of trying to co-opt Ukraine to join the organisation in 2013-14 testified, it is not competent, capable or even willing to act as an ordering agent in Europe. On the contrary, the dramatic 
escalation in Ukraine in 2014 has been followed by a pattern where Russia has proved ruthless in the application of power to challenge and to a degree overturn the current order on the regional level. Admittedly, compared with the West Russia is lacking in many of the key attributes of power. Its population is stagnating and its economy is weak and almost entirely reliant on the sale of hydrocarbons on increasingly turbulent world markets. Yet what it may suffer in the aggregate, it amply makes up in the skill and will to employ the wherewithal at its disposal (see Baldwin 1979: 163). When this is factored in, Russia's record of accomplishment, and indeed short- to midterm potential, looks more promising. Russia has also shown great acumen in projecting military means to achieve political ends beyond its borders both in its immediate vicinity in Ukraine and even beyond as the events in Syria have shown. This continued contestation is also a factor that feeds into the potential emergence of nonpolarity in Europe, discussed next.

\section{Causes and drivers of nonpolarity in Europe}

To a degree, the above narrative is compatible with traditional forms of ordering in international politics. It is possible that the process we are currently witnessing is merely 'normal' turbulence associated with a period of intense contestation that will be followed by the creation of a new or at least amended order in Europe (Gilpin 1981). Yet in recent years a myriad of factors and developments have warranted asking the question whether the notion of nonpolarity is in fact more applicable. By examining the factors outlined in the definition of an above ordering agent, we can see how the main contenders in Europe portray varying drivers for the rapid decline in the current order and augur the possible emergence of nonpolarity on the continent.

To begin with, one must note how the unified, even if concentric, western hegemony in Europe is rapidly unravelling. Both the USA and the European Union portray much less cohesion and ability to act in tandem as successful ordering agents than previously. Under Trump, the Transatlantic partnership has experienced growing strains, even signs of serious erosion. (The process is documented in Brookings 2020.) The Trump administration views the EU and its institutions with hostility and its European allies with growing suspicion. Over time, the Europeans, too, have started to lose faith in their partnership with the Americans. The relations between the EU and the USA have atrophied with no meaningful dialogue or interaction currently taking place between Brussels and Washington. Consequently, the ability of the two to coordinate their activities and channel their respective energies in the same direction has been lost. As a result, it is difficult to talk about western hegemony in Europe anymore. What is more, the whole idea of a unified 'West' is increasingly being questioned on both shores of the Atlantic (Kimmage 2020; Tcherneva 2018). This is a development that affects the European order negatively and has a major impact on the evolution of relations on the global level as well.

If the two former hegemons have found it hard to work together, the same applies to their roles individually in Europe. In the US case, the issue is not the wholesale atrophy in the capacity to act as an ordering agent. No one is suggesting that in 
terms of overall capacity or competence the USA is completely lacking or that it lacks economic or military power. But what it increasingly is lacking, is the ability, through the erosion of perceived legitimacy and the lack of essential willingness to uphold the current order globally and in Europe. This is due to the political variable that stems from the current period of soul-searching revolving around the perceived need to recalibrate the US global role and posture in light of the new era of 'Great Power Competition' that is seen as being in the offing. The Trump presidency has accentuated and aggravated these trends, but he is not the root cause behind them. Kagan (2018) might be right in arguing that Trump has struck a stake through the heart of the liberal world order, but the problem is not just him. The US role would be changing in any case. In the short term, a lot will depend on the Presidential elections in November 2020. But even if Trump is unseated, it will most probably affect mainly the mood and atmospherics in Transatlantic relations. That can be significant, but will not undo nor necessarily even repair the damage that stems from deep-seated structural factors and tensions between the USA and the EU (Polyakova and Haddad 2019).

Turning to the EU, we find it increasingly isolated, alone and adrift, essentially clinging to the vestiges of its preferred order globally and regionally without the necessary means to project or protect that very order. The fact that the EU does not seriously register as a military power would seem to exclude from the list of possible poles, yet it would be erroneous to discount it as an ordering agent. Economically the EU is still in a very strong position, even if the problems of governing the European common currency cast a shadow on its prospects. In addition, Waltz's (2000: 31) verdict concerning the Europeans two decades ago seems to hold: the EU still lacks the organisational ability and the collective political will to translate its sizable power potential into credible international actorness. Moreover, there are mounting signs that the EU is no longer acknowledged as a key player in global affairs, if indeed it ever was. On the contrary, European perspectives are increasingly sidelined in global politics. Increasingly, the EU is not the actor, but the stage upon which others act.

The EU's inability to project order, or at least stymie growing instability, is most visible around its own borders. The European Neighbourhood Policy (ENP) that was meant to result in a 'Ring of Friends' around the EU effectively collapsed in the Ukraine conflict. The aftermath of the so-called Arab Spring resulted in the tragic civil war in Syria and completed the current outcome that the Economist dubbed a 'Ring of Fire' around the Union (Haukkala 2017). None of this to argue that these developments are primarily the EU's fault—but to act as a successful ordering agent, one needs to be able to project stability and not just protest instability around you.

Internally the EU's situation is equally precarious. During the last decade, it has repeatedly succumbed into crises that have sapped its energies and legitimacy even in the eyes of its own citizens (Wivel and Wæver 2018). At times, it seems as if the Europeans are facing growing problems in keeping even their own EU house in order, as exemplified by Brexit and the growing internal fissures concerning economic governance and the rule of law in Europe (Krastev 2017; Zielonka 2018). It should, however, be pointed out that we are not talking about the potential collapse of the EU itself. Yet there exists serious doubt whether and to what extent the EU 
can keep up its role as an ordering agent even among its own ranks, let alone aspire to a successful ordering role externally.

The final contender, Russia, demonstrates very few or perhaps not at all signs of playing a constructive ordering role in Europe for the moment. On the contrary, it does not even aim to generate order elsewhere than at home and seems busy wielding a geopolitical wrecking ball to hasten the demise of the current order. Considering our definition for an ordering agent, Russia has fallen short during post-Cold War era, and even before, as exemplified by the collapse of the Soviet Union and its empire. Currently it does not have the economic power base to act as an ordering agent nor does it offer any coherent alternative to the order it is criticising. Currently Moscow's actions do not add up to a positive agenda nor does it seem to aspire to one. Consequently, the external appeal and legitimacy of Russia's agenda in Europe is very limited. Taken together, none of these attributes translate into a capacity to act as an ordering agent in the European setting.

This discussion is tentatively summarised in Table 3: tentatively, because to assess these findings with full confidence would obviously require more rigorous analysis. That said, it is nevertheless hoped that the thesis has enough prima facie plausibility so that it merits to be taken seriously and is subjected to more rigorous research and analysis in the future.

\section{Conclusions}

Europe has entered a period of relative decline and its role and heft in global politics is rapidly shrinking. There are deep structural forces at play, and the diminution in Europe's importance is inevitable. At the same time, these developments are compounded by the fact that the very order undergirding Europe's own security and stability is deteriorating. This article argues that this not only is due to normal geopolitical contestation, but is a sign that Europe is in danger of losing ordering agents, i.e. Great Powers capable, able and willing to create or sustain order on the continent.

The main driver behind these developments is the changing US power and role in Europe. Under Trump, Washington has lost its appetite to act as the bulwark of stability in Europe. This has resulted in the ongoing collapse of the "matryoshka hegemony', the previously complementary concentric US and EU ordering roles in Europe. To make matters worse, the EU is not up to the task on its own and, it seems, the final contender for the ordering role in Europe, Russia, is not even interested in it. In addition, the internal trajectories within both the EU and Russia point towards decreasing capacity for successful ordering agency. Therefore, it is time to put forward the question whether the conflict between the West and Russia is contributing to the relative decline of Europe in world politics at large, and whether the unintended consequence of this contestation could be hastening the arrival of a period of nonpolarity in Europe, with no power being able nor necessarily even willing to shoulder the responsibility of ordering and providing good stewardship in and over Europe.

We have no historical track record of nonpolarity in the modern era, yet we can surmise about its possible effects based on conceptual and empirical understandings 


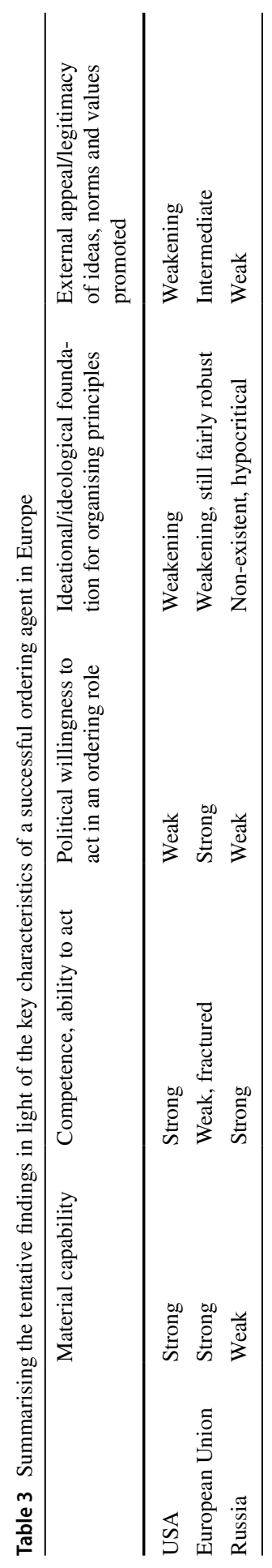


of international politics. It is argued that a period of nonpolarity would pose serious problems, for two reasons. Firstly, Europe is living in an era of high and constantly rising interaction capacity that creates both demands and challenges in terms of coordination and cooperation (Buzan 1993, 331). Trade and other flows, both legal and illicit, as well as the increasingly important cyber space all require governance and joint management. Secondly, we are living in an era of high complex interdependence (Keohane and Nye 1977) that also includes mounting risks and challenges, some of them potentially catastrophic, even on a global scale (Ord 2020).

Handling these issues requires order and ordering agents. Order is the prerequisite for governance without which the risks inherent in our current world become very difficult, practically impossible to control or contain. The haphazard and uneven response to the Covid-19 coronavirus pandemic is a case in point. These are global trends, but it is argued that in Europe these issues are even more pertinent because for the last three decades, and more, Europe has generated its own web of densely institutionalised forms of cooperation, rules and regulations that require capable ordering agents for their continued existence. Russia might find some of these entanglements too close for comfort, but, it is argued, they, along with the US military overlay, have been instrumental in keeping the peace on the continent.

A way to read the current situation is to envisage it as a dialectical process where the western thesis has now been fully countered by the Russian antithesis. The synthesis remains still to be seen-but it is not an easy one to locate or arrive at due to the essential incommensurability of current positions. Indeed, the crux of the potential for nonpolarity in Europe is the fact that currently no one can impose an order anymore, while the sides are deeply divided and unable to agree on a new one. One avenue forward might be a return to some form of a balance of power in Europe. Yet the discrepancies between the various forms of power are probably too large to allow for that. Moreover, the internal dynamics within the main potential ordering agents are such that the situation is unlikely to remain stable enough to allow for a sustainable recalibration of the European setting. On the contrary, a safer prognosis seems to be the continued and perhaps even expanding turbulence in Europe.

Over time, the lack of good stewardship over Europe will result in further erosion of norms and institutions, generating growing friction and potential for conflict. This means missed economic opportunities and increasing inability to work successfully together to tackle wider problems facing Europe and the world. More worryingly, the hard-won gains of the past 80 years are at risk of being undone. An open conflict between Russia and the West cannot be excluded. This should be a cause for concern and rallying call for more responsible policies and politics. The emergence of a nonpolar Europe cannot or should not be in anyone's interest. What is more, in the twenty-first century a Great Power worthy of the name should be held to a higher standard in terms of providing building blocks for stability and order on both the regional and global levels than is currently the case. This is not a new idea: as Brown (2004) has argued, Great Powers, simply due to the virtue of their size and importance, have always been held to a higher standard than other powers.

In the final analysis, the advent of possible nonpolarity in Europe depends on political choices by the main protagonists. Indeed, this article is not a prognosis that nonpolarity in Europe is inevitable. Three questions in particular stand out that 
will affect the future developments: (1) the evolution of the US role globally and in Europe; (2) the EU's ability to overcome its current crises and to develop more robust forms of international actorness; and (3) the future of Russia's conflict with the West as well as the evolution of its appetite to seek more constructive roles and openings in Europe. Nonpolar Europe can still be avoided by political choices and responsible policies by the main actors that foster the return of capable, credible and committed ordering agents in Europe.

\section{Compliance with ethical standards}

Conflict of interest The author asserts no conflict of interest with this article.

\section{References}

Aalto, P. 2006. European Union and the Making of a Wider Northern Europe. London: Routledge.

Allison, G. 2017. Destined for War: Can America and China Escape Thucydides's Trap?. Boston: Houghton Mifflin Harcourt.

Arreguin-Toft, I. 2001. How the Weak Wins Wars? A Theory of Asymmetric Conflict. International Security 26(1): 93-128.

Asmus, R.D. 2002. Opening NATO's Door. How the Alliance Remade Itself for a New Era. New York: Columbia University Press.

Baldwin, D.A. 1979. Power Analysis and World Politics: New Trends Versus Old Tendencies. World Politics 31(2): 161-194.

Baldwin, D.A. 1989. Paradoxes of Power. Oxford: Blackwell.

Baldwin, D.A. 2002. Power and International Relations. In Handbook of International Relations, ed. W. Carlsnaes, T. Risse, and B.A. Simmons. Thousand Oaks: SAGE.

Bremmer, I. 2012. Every Nation for Itself: What Happens When No One Leads the World. New York: Portfolio/Penguin.

Brookings. 2020. Trans-Atlantic Scorecard. https://www.brookings.edu/series/trans-atlantic-scorecard/. Accessed 13 June 2020.

Brooks, S.G., and W.C. Wohlforth. 2008. World Out of Balance: International Relations and the Challenge of American Primacy. Princeton: Princeton University Press.

Brown, C. 2004. Do Great Powers Have Great Responsibilities? Great Powers and Moral Agency. Global Society 18(1): 5-19.

Bull, H. 1995. The Anarchical Society: A Study of Order in World Politics, Second Edition with a New Foreword by Stanley Hoffmann. Basingstoke: Macmillan.

Bull, H., and A. Watson. 1984. The Expansion of International Society. Oxford: Clarendon Press.

Buzan, B. 1993. From International System to International Society: Structural Realism and Regime Theory Meet the English School. International Organization 47(3): 327-352.

Deyermond, R. 2009. Matrioshka Hegemony? Multi-Levelled Hegemonic Competition and Security in Post-Soviet Central Asia. Review of International Studies 35(1): 151-173.

Diez, T., and R. Whitman. 2002. Analysing European Integration: Reflecting on the English SchoolScenarios for an Encounter. Journal of Common Market Studies 40(1): 43-67.

Dragneva, R., and K. Wolczuk (eds.). 2013. Eurasian Economic Integration: Law, Policy and Politics. Cheltenham: Edward Elgar.

Forsberg, T., and H. Haukkala. 2016. The European Union and Russia. London: Palgrave.

Franke, U. 2015. War by Non-Military Means. Understanding Russian Information Warfare. FOR-R4065-SE, March 2015. Stockholm: FOI.

Friedner Parrat, C. 2017. On the Evolution of Primary Institutions of International Society. International Studies Quarterly 61(3): 623-630.

Gilpin, R. 1981. War and Change in World Politics. Cambridge: Cambridge University Press. 
Goldgeier, J.M., and M. McFaul. 2003. Power and Purpose. U.S. Policy Toward Russia After the Cold War. Washington, DC: Brookings.

Goldin, I., and M. Mariathasan. 2016. The Butterfly Defect: How Globalization Creates Systemic Risks, and What to Do about It. Princeton: Princeton University Press.

Gretskiy, I., E. Treshchenkov, and K. Golubev. 2014. Russia's Perceptions and Misperceptions of the EU Eastern Partnership. Communist and Post-Communist Studies 47(3-4): 375-383.

Haass, R.N. 2008. The Age of Nonpolarity. What Will Follow U.S. Dominance. Foreign Affairs 87(3): 44-56.

Halliday, F. 1994. Rethinking International Relations. Basingstoke: Palgrave.

Haukkala, H. 2008. The European Union as a Regional Normative Hegemon: The Case of European Neighbourhood Policy. Europe-Asia Studies 60(9): 1601-1622.

Haukkala, H. 2016. The Perfect Storm. Or What Went Wrong and What Went Right for the EU in Ukraine. Europe-Asia Studies 68(4): 653-664.

Haukkala, H. 2017. The EU's Regional Normative Hegemony Encounters Hard Realities: The Revised European Neighbourhood Policy and the Ring of Fire. In The Revised European Neighbourhood Policy. Continuity and Change in EU Foreign Policy, ed. D. Bouris and T. Schumacher, 77-94. Basingstoke: Palgrave Macmillan.

Hill, W.H. 2018. No Place for Russia. European Security Institutions Since 1989. New York: Columbia University Press.

Hoffmann, S. 1990. International Society. In Order and Violence: Hedley Bull and International Relations, ed. J.D.B. Miller and R.J. Vincent, 13-37. Oxford: Clarendon Press.

Ikenberry, G.J. 2001. After Victory: Institutions, Strategic Restraint, and the Rebuilding of Order After Major Wars. Princeton: Princeton University Press.

Ikenberry, G.J. 2018. The End of Liberal International Order? International Affairs 94(1): 7-23.

Ikenberry, G.J., and D.H. Nexon. 2019. Hegemony Studies 3.0: The Dynamics of Hegemonic Orders. Security Studies 28(3): 395-421.

Kagan, R. 2018. The Jungle Grows Back. American and Our Imperiled World. New York: Alfred A. Knopf.

Kegley Jr., C.W., and G. Raymond. 1994. A Multipolar Peace? Great-Power Politics in the Twenty-first Century. New York: St. Martin's Press.

Keohane, Robert O., and Joseph S. Nye. 1977. Power and Interdependence: World Politics in Transition. Boston: Little, Brown.

Keukeleire, S., and T. Delreux. 2014. The Foreign Policy of the European Union, 2nd ed. Basingstoke: Palgrave Macmillan.

Kimmage, M. 2020. The Adandonment of the West: The History of an Idea in American Foreign Policy. New York: Basic Books.

Krastev, I. 2017. After Europe. Philadephia: University of Pennsylvania Press.

Leander, A. 2006. Paradigms as a Hindrance to Understanding World Politics. Cooperation and Conflict 41(4): 370-376.

Little, R. 2014. The Balance of Power in International Relations: Metaphors, Myths and Models. Cambridge: Cambridge University Press.

Manners, I. 2002. Normative Power Europe: A Contradiction in Terms? Journal of Common Market Studies 40(2): 235-258.

Marten, K. 2017. Reconsidering NATO Expansion: A Counterfactual Analysis of Russia and the West in the 1990s. European Journal of International Security 3(2): 135-161.

Mastanduno, M. 1997. Preserving the Unipolar Moment: Realist Theories and U.S. Grand Strategy after the Cold War. International Security 21(4): 49-88.

Mearsheimer, J.J. 2001. The Tragedy of Great Power Politics. Updated ed. New York: W.W. Norton.

Mearsheimer, J.J. 2019. Bound to Fail The Rise and Fall of the Liberal International Order. International Security 43(4): 7-50.

Menon, R., and E. Rumer. 2015. Conflict in Ukraine. Unwinding of the Post-Cold War Order. Cambridge: The MIT Press.

Monteiro, N.P. 2014. Theory of Unipolar Politics. New York: Cambridge University Press.

Nye, J.S. 2004. Soft Power: The Means to Success in World Politics. New York: Public Affairs.

Nye, J.S. 2011. The Future of Power. New York: Public Affairs.

Ord, T. 2020. The Precipice: Existential Risk and the Future of Humanity. New York: Hachette Books.

Philpott, D. 2001. Sovereignty: An Introduction and Brief History. Journal of International Affairs 48(2): 353-368. 
Polyakova, A., and B. Haddad. 2019. Europe Alone: What Comes After the Transatlantic Alliance. Foreign Affairs 98(4): 109-120.

Putin, V. 2007. Speech and the Following Discussion at the Munich Conference on Security Policy, 10 February 2007. http://en.kremlin.ru/events/president/transcripts/24034. Accessed 13 June 2020.

Smith, K.E. 1999. The Making of EU Foreign Policy: The Case of Eastern Europe. Basingstoke: Macmillan.

Sørensen, G. 2008. The Case for Combining Material Forces and Ideas in the Study of IR. European Journal of International Relations 14(5): 5-32.

Sørensen, G. 2019. Pyrrhic Victory: A World of Liberal Institutions, Teeming with Tensions. In International Institutions and Power Politics: Bridging the Divide, ed. A. Wivel and T.V. Paul, 53-72. Washington, DC: Georgetown University Press.

Stent, A. 2014. The Limits of Partnership. U.S.-Russian Relations in the Twenty-First Century. Princeton: Princeton University Press.

Talbott, S. 2002. The Russia Hand. A Memoir of Presidential Diplomacy. New York: Random House.

Tcherneva, V. 2018. The End of the Concept of 'the West'? ECFR Commentary, 18th May, 2018. https ://www.ecfr.eu/article/commentary_the_end_of_the_concept_of_the_west. Accessed 13 June 2020.

Trenin, D. 2009. Russia's Spheres of Interests, not Influence. The Washington Quarterly 32(4): 3-22.

Waltz, K.N. 1979. Theory of International Politics. New York: McGraw-Hill.

Waltz, K.N. 1993. The Emerging Structure of International Politics. International Security 18(2): 44-79.

Waltz, K.N. 2000. Structural Realism after the Cold War. International Security 25(1): 5-41.

Wiener, A. 2014. A Theory of Contestation. Berlin: Springer.

Williams, J. 2006. Order and Society. In The Anarchical Society in a Globalized World, ed. R. Little and J. Williams, 13-34. Basingstoke: Palgrave Macmillan.

Wilson, A. 2014. Ukraine Crisis: What it Mean for the West. New Haven: Yale University Press.

Wivel, A., and T.V. Paul (eds.). 2019. International Institutions and Power Politics: Bridging the Divide. Washington, DC: Georgetown University Press.

Wivel, A., and O. Wæver. 2018. The Power of Peaceful Change: The Crisis of the European Union and the Rebalancing of Europe's Regional Order. International Studies Review 20(1): 317-325.

Young, O.R. 1989. International Cooperation: Building Regimes for Natural Resource and the Environment. Ithaca: Cornell University Press.

Zielonka, J. 2018. Counter-revolution: Liberal Europe in Retreat. Oxford: Oxford University Press.

Publisher's Note Springer Nature remains neutral with regard to jurisdictional claims in published maps and institutional affiliations. 